Взаимоотношения ЕС и США начались в 90х годах в связи с подписанием Трансатлантической декларации, которая, в том числе, регулировала вопросы, касающиеся экономических отношений.

Важным этапом в развитии отношений стал саммит, проходивший в Лондоне в 1998 году, в ходе которого было подписан такой документ, как Соглашение о трансатлантическом экономическом партнёрстве. Данный документ был создан для регулирования торговых отношений, включая вопросы либерализации международной торговли в рамках ВТО.

В апреле 2007 г. на саммите в Вашингтоне была одобрена Декларация об основных направлениях усиления экономической интеграции. На основе этого документа был создан ТЭС, который должен был развивать сотрудничество в сферах регулирования торговли, защиты прав интеллектуальной собственности, обеспечения стандартов безопасности производства и поставок экспортных товаров, регулирования финансовых рынков, поддержки инноваций и передовых технологий, регулирования и стимулирования инвестиций.

Между ЕС и США часто возникают споры, касающиеся экономических взаимоотношений. Однако, как показывает статистика, экспорт и импорт товаров все же достаточно хорошо налажены, например, одним из основных торговых партнеров по экспорту в США является Германия, которая является членом ЕС. Помимо указанной страны, также крупными партнерами являются Италия и Великобритания.

Говоря об импорте из США, одним из главных партнеров выступает Великобритания, реализующая американские товары.

Следовательно, можно говорить о том, что экономические отношения между ЕС и США динамично развиваются.

Обобщая вышеизложенное, можно говорить о том, что экономические отношения Европейского союза с другими государствами-это отношения, касающиеся обмена, производства, распределения тех или иных благ. Экономические отношения возникают в результате подписания различных Соглашений, регулирующих рассматриваемую область. Введение экономических санкций ЕС против той или иной страны может негативно сказываться на экономике стран участников ЕС, что подтверждается результатом введения санкций против Российской Федерации.

$$
* * *
$$

1. Соглашение о партнерстве и сотрудничестве, учреждающее партнерство между Российской Федерацией, с одной стороны, и Европейскими сообществами и их государствами-членами, с другой стороны (заключено на о. Корфу 24.06.1994)

2. Глущенко Ю.Н. Состояние, проблемы и перспективы сотрудничества США и ЕС в экономической сфере / Проблемы национальной стратегии. 2015. С.12.

3. Жарикова А.Р. Экономические отношения ЕС и США / Е-Scio. 2020.7 с.

4. Савона Р. Хронология введения санкций и ответные меры России в 2014-2015 годах / Электронный ресурс: https://ria.ru/20151125/1328470681.html (дата обращения: 24.11.2021)

5. Право Европейского Союза, Общество с ограниченной ответственностью Издательство ЮРАЙТ, 2018

6. Казаченок О.П. Юридическая конструкция международного ипотечного кредитования в РФ и странах Европы, Legal Concept, 2016

\title{
Мотовилина А.В. \\ Интеллектуальная собственность: ее сущность, объекты и роль в инновационной экономике государств
}

Отдел полищии 2 Управления МВД России по г. Волгограду

(Россия, Волгоград)

doi: 10.18411/trnio-01-2022-186

Научный руководитель: Копьев А.В.

\section{Аннотация}

В работе рассмотрены вопросы, касающиеся сущности и объектов, за которыми законодатель дает возможность закрепить исключительные права, а также указывается значение интеллектуальной собственности в развитии инновационной экономики. 
Ключевые слова: интеллектуальная собственность, правообладатель, инновации, инновационная экономика, компании.

\section{Abstract}

The paper considers issues related to the essence and objects for which the legislator makes it possible to secure exclusive rights, and also indicates the importance of intellectual property in the development of an innovative economy.

Keywords: intellectual property, copyright holder, innovation, innovative economy, companies.

В настоящее время происходит активное развитие экономики различных стран. При этом, одним из ее типов является экономика, обозначаемая как инновационная, базисом которой служат различные инновации, дающие возможность постоянно совершенствовать различные технологии, процессы, продукцию. Как отмечается, такой тип экономики предоставляет отдельным государствам, где она развита на высоком уровне, определенное превосходство на мировом рынке. Одним из основных понятий в данном случае выступает интеллектуальная собственность.

Давая общую характеристику интеллектуальной собственности, можно говорить о том, что законодатель установил ряд объектов, на которые может распространяться защита. К ним относятся:

1. произведения науки, литературы и искусства;

2. программы для электронных вычислительных машин (программы для ЭВМ);

3. базы данных;

4. исполнения;

5. фонограммы;

6. сообщение в эфир или по кабелю радио- или телепередач (вещание организаций эфирного или кабельного вещания);

7. изобретения;

8. полезные модели;

9. промышленные образцы;

10. селекционные достижения;

11. топологии интегральных микросхем;

12. ноу-хау;

13. фирменные наименования;

14. товарные знаки и знаки обслуживания;

15. географические указания;

16. наименования мест происхождения товаров;

17. коммерческие обозначения.

Указанный перечень является закрытым. В случае создания результата интеллектуальной деятельности лицо может обратиться в соответствующий орган и требованием о признание за ним исключительных прав, которые дадут ему возможность владеть, пользоваться и распоряжаться объектом по своему усмотрению.

Законодатель не устанавливает запрета на количество правообладателей, следовательно, одним объектом могут владеть несколько лиц. При этом, нормами права установлено, что каждый из них, по общему правилу, может пользоваться им по своему усмотрению, если в соглашении эти субъекты не установили другое положение.

Устанавливается и определенный режим охраны таких результатов. В случае, если другое лицо без разрешения воспользуется чужим объектом, правообладатель имеет право обратиться в органы для привлечения нарушителя к ответственности. Выбор способа защиты зависит от того, права на какой именно объект были нарушены.

Вопросы, касающиеся защиты исключительных прав в настоящее время достаточно актуальны, особенно в Российской Федерации. Опираясь на статистические данные, можно 
говорить о том, что нарушение таких прав происходит достаточно часто и с каждым годом увеличивается, несмотря на то, что законодательство страны в этой области хорошо развито. Например, в 2018 году Роспатент рассмотрел 2134 заявления о нарушении исключительных прав, в 2019-2341 заявления, в 2020-2445 заявлений.

Перейдем к роли интеллектуальной собственности в инновационной экономике.

Инновации создаются человеком, их результат, как правило, оформляется в виде исключительных прав на тот или иной объект, тем самым, у физического или юридического лица возникает право интеллектуальной собственности.

Компании, пользующиеся инновационными технологиями, получают их либо путем разработки, либо путем заключения договоров с правообладателями на предмет возможности их использования в своих определенных целях. Как правило, крупные компании самостоятельно создают результаты интеллектуальной деятельности, а затем регистрируют права на них, поскольку видят это более выгодным.

Интеллектуальная собственность, в первую очередь, оказывает большое влияние на механизм создания добавочной стоимости, в качестве средства капитализации активов различных компаний, а также является инвестиционным ресурсом. Как правило, показателем такого типа экономики является различные зарегистрированные патенты, а также секреты производства, инновационные технологии и т.д.

В мире существует функционирует большое количество компаний, которые используют зарегистрированные за ними исключительные права на те или иные объекты интеллектуальной деятельности, поскольку это дает им возможность более успешно конкурировать на рынке, разрабатывать особые продукты, которые не могут произвести другие компании, либо реализовывать продукты и услуги, имеющиеся на рынке, но проигрывающие, например по качеству.

Инновационные продукты предоставляют возможность более оптимально управлять различными информационными, а также материальными потоками, следовательно, дают возможности предприятиям достигнуть более высокого уровня управления. К тому же, отмечается, что о при использовании таких объектов совместно с рядом дополнительных услуг, создается более успешный и полезный эффект от результата деятельности, которой занимается та или иная компания.

В качестве одного из успешных примеров использования инноваций, в своей работе приводит Пашигорева Г.И, которая указывает, что в области логистики широко используются специальные информационные системы, с помощью который компаниям удается проводить логистические операции слажено и оперативно. Еще одним примером является использование системы WMS, которая дает возможность автоматизировать различные складские операции.

Обобщая изложенное, можно говорить о том, что интеллектуальная собственность является основой развития инновационной экономики. Инновации, используемые в такой деятельности, открывает широкие перспективы для различных компаний, а также выводит государство на более высокий уровень на мировом рынке. В настоящее время инновационная экономика хорошо развита в таких странах как США, Канада, Япония, Южная Корея и т.д. В России, сейчас, невысокий уровень развития инновационной экономике, который объясняется тем, что достаточно мало в производствах используются результаты интеллектуальной деятельности, в связи с чем необходимы изменения и выхода на более высокий уровень.

$$
* * *
$$

1. Гражданский кодекс Российской Федерации (часть четвертая) от 18.12.2006 N 230-Ф3 (ред. от 11.06.2021) (с изм. и доп., вступ. в силу с 01.08.2021)

2. Новоселова Л. А. Право интеллектуальной собственности. Учебник. М.: Юрайт, 2019. 344 с.

3. Орлова Л.Н. Инновационная экономика: факторы и противоречия развития, уровни формирования / Вестник евразийской науки. 2015. 15 с.

4. Статистические данные о рассмотрении административных споров, связанных с правовой охраной результатов интеллектуальной деятельности и средств индивидуализации / Электронный ресурс: https://rospatent.gov.ru/content/uploadfiles/rassm-adm-spor-2020.pdf (дата обращения 30.11.2021) 